\title{
Social Accountability in Italian Listed Companies: \\ Communication or Voluntary Disclosure?*
}

\author{
Elena Gori \\ University of Florence, Florence, Italy \\ Alberto Romolini \\ International Telematic University Uninettuno, Rome, Italy \\ Silvia Fissi \\ University of Florence, Florence, Italy
}

\begin{abstract}
In recent years, corporate social responsibility (CSR) has become an emerging topic. CSR represents the need for companies to voluntarily concern themselves with the social and environmental impacts on their activity. This paper aims to understand whether listed Italian companies are actually making voluntary disclosures or simply promoting their image to stakeholders. Research has been carried out using an inductive method with a theoretical sampling. We analyse CSR documentation produced by Italian businesses making up the FTSE ECPI Leaders Index of the Italian Stock Exchange and compare their documents with those produced by the Dow Jones Sustainability Europe 40 Index companies. The results confirm recent studies on the quality of Italian CSR. The documents produced by the sample companies show their attention to CSR issues, since in fact these companies draw up a wide spectrum of interdependent reports and produce full documentation using GRI social model reporting. Moreover, increasing standardization brings improvements in consistency and comparability and at the same time discourages manipulation of these documents solely for self-promotion. Finally, comparison with European companies suggests that Italian ones are somewhat "backward" in the types of documents produced, in choice of social reporting models to be used and in external control. The latter-external control—tends to encourage voluntary disclosure, as against an exercise in communications.
\end{abstract}

Keywords: corporate social responsibility (CSR), Italian listed companies, social accountability, sustainability reporting

\section{Introduction}

Political pressure from international organisms such as the OECD and the European Union, often exercised

\footnotetext{
* Although this work represents a joint study by the authors, sections "Introduction” and "Conclusion" can be attributed to Elena Gori; "Theoretical Framework" and "The DJSE” to Alberto Romolini; "Method" and "The FELI" to Silvia Fissi. This research was supported by CUSAS, University of Florence.

Elena Gori, Ph.D., Assistant Professor, Department of Business Administration, University of Florence.

Alberto Romolini, Ph.D., Assistant Professor, International Telematic University Uninettuno.

Silvia Fissi, Ph.D., Department of Business Administration, University of Florence.

Correspondence concerning this article should be addressed to Elena Gori, Faculty of Economics, University of Florence, Via delle Pandette 9, Florence 50127, Italy. E-mail: elena.gori@unifi.it.
} 
through publications or specially constituted bodies, have contributed to the divulgation and, consequently, the adoption of social accountability principles by public, private, and non-profit companies.

The United Nations Declaration on the Human Environment (1972) was one of the first documents through which the international community recognised the environmental problem and the need for sustainable development processes (Caldwell \& Weiland, 1997). Reference was made, however, not to businesses but to national governments, considered to be of major importance in formulating and carrying out public policies that helped to spread the concept of sustainable development. In the years that followed, numerous other documents were to emphasise the importance of social accountability, involving citizens and, later, also businesses.

On a European level, attention to the social dimension dates from the second half of the 1990s (Falkner, 1998). In particular, in July 2001, the European Commission published a Green Paper-Promoting a European framework for corporate social responsibility, which pointed out that:

... although the prime responsibility of a company is generating profits, companies can at the same time contribute to social and environmental objectives, through integrating corporate social responsibility as a strategic investment into their core business strategy, their management instruments and their operations. (European Commission, 2001, p. 4)

In other words, the commission holds that corporate social responsibility should be considered an investment and not a cost since, going beyond legal requirements, it allows an increase in competitiveness for multinationals, small-to-medium enterprises (SMEs) and micro-enterprises.

The great efforts of international bodies in spreading the principles and theories of corporate social responsibility (hereafter CSR) have had two effects—-the first, on a political level and the second on a more strict business level.

On an institutional level, policies of these international bodies, particularly of European ones, in support of CSR have led to the founding of government programmes for encouraging social accountability within national boundaries. In Italy, the phenomenon of Europeanisation (Cotta \& Verzichelli, 2007) has gradually led the government to adapt to EU policies and institutions. This is not mere acceptance at national level of European policies, but constant interaction between the two institutional macro-levels, both in formulating and in carrying out the policies (Graziano \& Vink, 2007). As far as CSR is concerned, the Italian government has created a policy to raise awareness that has been welcomed and accepted by the social partners, first and foremost, by the trade unions ${ }^{1}$.

From a business-management point of view, the first opinions on corporate social accountability came from the United States in the 1920s (Donham, 1929; Gay, 1927). These authors constantly refer to the responsibility of businessmen and to the importance of management science as a potential trigger of social well-being, created through corporate activity. Nonetheless, a univocal and universally accepted definition of CSR has not yet been constructed (Carroll, 1999; Thomas \& Nowak, 2006) and only in recent years have a precise role and a specific evaluation been given to “socially responsible” businesses (Garriga \& Melé, 2004).

These two observations underlie the second effect of the widespread adoption of CSR principles - the need, increasingly felt as CSR spread to more businesses, to establish an evaluation procedure for social reporting. In fact, the corporation's results, not only financial, but also social and environmental according to the triple bottom line approach (Elkington, 1998), must be publicly communicated. This social accountability, though using its

${ }^{1}$ This is the "CSR CSC Project” created by the Ministry of Employment and Social Policies in 2002. 
own instruments for performance measurement and external communication (Bendell, 2005), must be used in conjunction with and complementary to the compulsory instruments (financial statements), in a unitary and systemic manner (Griffin \& Mahon, 1997).

Leipziger (2003) identified no less than 32 reporting instruments. In fact, corporate decisions as how to manage their social accountability and stakeholder relations are influenced by the particular nature of their sector and their own corporate culture. Primarily, it is their concept of social accountability that dictates their approach to the documents used by them to diffuse their performance results (European Commission, 2001, p. 17). So paradoxically, there might be as many types of social reporting as there are corporations. Nonetheless, for reporting to be useful, it must be drawn up according to generally accepted principles. The main instruments of CSR, therefore, can be summarised as follows: code of ethics, social reporting and management system.

With increasing diffusion of CSR came the need to report results to stakeholders, using the above mentioned social accountability instruments. It therefore became necessary to identify minimum levels of standardisation and uniformity, which led, firstly at an international level and then in Italy, to definition of social reporting models (Sacconi et al., 2003).

The main models presently in use by Italian businesses in drawing up the most common documents of social reporting—social, environmental and sustainability reports—are AccountAbility 1000 (AA1000), Gruppo di Studio sul Bilancio Sociale (Social Reporting Study Group-GBS), Global Reporting Initiative (GRI) and Life Cycle Assessment (ISO 14040).

Although by now the connection between competitive advantage and responsible corporate behaviour has been analysed (Poddi \& Vergalli, 2008; Porter \& Kramer, 2006), recent studies nevertheless indicate that public and private companies often produce social accountability documents solely to improve their market image (Cooper \& Owen, 2007; Gray, 2001; O’Dwyer, 2003; Owen, Swift, Humphrey, \& Bowerman, 2000; Owen, Swift, \& Hunt, 2001).

The aim of this research is to examine to what extent Italian public companies apply the key principles of CRS and to verify, if possible, that these principles are not instrumentalised, turning "ethics into a label". In other words, we believe this analysis of public companies, operating in a highly competitive global market with excellent financial and economic results, might show an attention to CSR, interpreted as a new means of communication of the possible effects of corporate activity (Abbort \& Monsen, 1979).

\section{Theoretical Framework}

Accountability is part of a wider concept of CSR, to be interpreted as the need for businesses to give an account of themselves to the community or to individuals interested in learning about their activity.

CSR is strongly related to stakeholder theory (Donaldson \& Preston, 1995; Freeman, 1984). The corporation represents a centre on which is focused the expectations of various groups of stakeholder. It has the difficult task of harmonising and responding to these often-diverging expectations. Attention on CSR grew up at the time when the posit, whereby a company automatically achieved social ends simply by maximising profit, was being questioned (Friedman, 1962). On looking closely, corporate activity produces social costs that are not considered in determining profits. So CSR compels the company to control the social and environmental effects of its activity, thus becoming a social institution for survival and development. As such, it actively contributes to 
improving the quality of life in its community, to conserving the environment, to creating and safeguarding employment and to educating consumers.

The importance of CSR is amplified by the consideration that businesses using this type of approach can obtain better economic and financial results (McGuire, Sundgren, \& Schneeweis, 1988; Orlitzky, Schmidt, \& Rynes, 2003; Waddock \& Graves, 1997). Choi, Kwak, and Choe (2010) found a positive correlation between CSR and financial performance. In other words, it is strategic for a business to include elements of social accountability among its aims, not only in order to improve stakeholder relations, but also to increase its own profitability level. Certain key elements for the success of CSR have been identified, such as stakeholder engagement, corporate leadership, and priority of CSR in corporate strategies and integration of CSR into systems of planning, programming and controlling (Morimoto, Ash, \& Hope, 2004). But an aspect on which studies do not agree is the need to regulate CSR processes. Some authors (Morimoto, Ash, \& Hope, 2004) believe it to be a factor of success, while others maintain that the voluntary nature of social reporting is an essential requisite (Metaxas \& Tsavdaridou, 2010).

Instead, some scholars (Aupperle, Carrol, \& Hatfield, 1985; McWilliams \& Siegel, 2000) declare that CSR has a neutral or negative impact on financial performance. Others argue that companies are assumed to be socially responsible because they anticipate benefits from these actions (Gamerschlag, Möller, \& Verbeeten, 2011). In other words, a company is engaged in CSR if benefits are greater than costs.

In these recent years of general economic crisis, the question of CSR has emerged strongly as an element of communication between businesses and stakeholders (Egri \& Ralston, 2008). Companies should avoid approaching sustainability issues in terms of "image” or purely as aspect of marketing (Graves \& Waddock, 2000) but they should include the theme of sustainability in corporate strategies and business management system.

A growing number of businesses have been noted, starting out on the social accountability process that is adopting various instruments, such as the code of ethics or environmental, social or sustainable reporting. Companies may be driven towards doing social reporting, having firmly introduced these new principles and values into their management. But there may also be motives of communications, marketing and consensus management, especially in times of negative economic growth.

On this point, some of the literature is engaged in studying not only the diffusion of CRS tools, but also the credibility of information produced. Contributions here mostly concentrate on developed countries (Adams, Hill, \& Roberts, 1998; Andrew, 2010; Guthrie \& Parker, 1990; Gray, Kouhy, \& Lavers, 1995a, 1995b). Some more recent works, however, analyse developing zones (Bird \& Smucker, 2007).

For the developing nations, particularly in Asia, studies have aimed at evaluating the level of CSR development, analysing the approach used in reporting and the presence of control procedures. The results show a prevalence of the qualitative approach in reports produced, with scarce attention to internal and external audits (Azim, 2009; Thompson \& Zakaria, 2004).

Other researches into CSR concentrate not so much on the geographic dimension, but on the sector of corporate activity (Al-bdour, Ellisha, \& Soh Deng, 2010; Genier, Stamp, \& Pfitzer, 2009; Hartmann, 2011), or on small-to-medium enterprises (SMEs) (Spence, Jeurissen, \& Rutherfoord, 2000; Spence \& Lozano, 2000; Thompson \& Smith, 1991).

Specific reference is also made to the Italian situation where interest in matters of social accountability is 
high and it is a well-consolidated practice. Perrini, Pogutz, and Tencati (2006) demonstrated that Italian companies have a positive attitude towards CSR and that Italy is at the forefront of CSR initiatives in Europe. The same research shows that the main reasons underlying CSR adoption are related to company image and relations with the local community. Pedrini and Ferri (2011) focused on corporations listed in the Italian Stock Exchange and also considered sustainability and social reporting. They observed that $28 \%$ of listed companies analysed draw up sustainability or social reports.

Moreover, the KPMG's International Survey shows that in 2011 Italian companies reached high levels of maturity and quality of communication in social reporting. Italian companies indeed rated high in terms of professionalism of their internal system and external accountability. Moreover, $74 \%$ of the Italian companies in KPMG's survey are involved in social reporting. The results of this study show that European companies, and Italian ones, are worldwide leaders that have been doing CSR reporting for over a decade.

Other authors (Russo \& Tencati, 2009) suggest analysing the relationship between CSR and SMEs because the main part of the literature is focused on large companies. This has recently been studied by some authors in the Italian context (Perrini, 2006; Perrini, Russo, \& Tencati, 2007). A recent study by Unioncamere (2003) found increased diffusion of social accountability among SMEs, regardless of their sector, probably because of links to the economic and social fabric of their local areas.

However, the topic of these studies is the relationship between CSR and strategy both in micro, small and medium companies. Mio (2010) demonstrated a functional relationship between the incorporation of CSR strategy and the quality of sustainability reports in Italian multi-utility listed companies.

On the basis of results of our analysis of the literature, our hypothesis is that in Italy social accountability of listed companies is a consolidated practice of corporate strategy and management and not only a means of promoting their image.

\section{Method}

The research in this study was carried out using the inductive method, typical of business administration.

To verify our hypothesis formulated as a logical consequence of theories found in the literature, that is to say, that social reporting is a voluntary disclosure and not an incidental phenomenon, theoretic sampling was carried out (Patton, 2002, pp. 230-242). This was actually sampling by extreme cases, as we selected the Italian companies with the best performances, from a voluntary reporting point-of-view. In the past, numerous authors (Covey, 1990; Peters \& Waterman, 1988) have adopted this method for their management studies, choosing a group—sometimes arbitrarily—of "extreme leaders" thought to be particularly effective.

For our study, we have chosen to analyse CSR documentation produced by Italian businesses making up the FTSE ECPI Leaders Index (hereafter FELI) of the Italian Stock Exchange (Borsa Italiana)².

\footnotetext{
2 The FTSE ECPI Italia SRI Indices are an instrument for representing environmental, social and governance (ESG) issues in investment strategies. They can be used to evaluate performance of ESG-oriented funds and as a basis for index funds and structured products. Medium to high capitalised shares in the FTSE Italia All-Share index can be included in the FTSE ECPI Italia SRI indices. Periodically, public documentation available (financial statements, Internet sites, sustainability reports, etc.) of companies that might be included in the indices is reviewed. Information gathered is used to determine an ESG rating used to classify the companies and construct the index baskets. There are two types of index: The FTSE ECPI Italia SRI Benchmark and the FTSE ECPI Italia SRI Leaders (www.ftse.com).
} 
FELI considers the economic, social and governance performances of public companies and assesses their ability in facing problems of this kind. The index is made up of ordinary shares issued by public companies on the Borsa Italiana's MTA market, which show excellent economic, social and environmental (ESG) characteristics. It only includes shares with an ECPI evaluation of "EE" or higher ${ }^{3}$. The index is weighted on the basis of correct capitalisation for floating shares and comprises a process to limit the weight of larger sized shares.

Index contents on 30th September 2010, showing companies and their sectors, are indicated in Table 1.

Table 1

The FELI on 30th September, 2010

\begin{tabular}{|l|l|}
\hline Company & Super sector \\
\hline Acea Spa & Utilities \\
\hline Atlantia Spa & Industrial Goods \& Service \\
\hline Autogrill Spa & Travel \& Leisure \\
\hline Banca Monte dei Paschi di Siena Spa & Banks \\
\hline Brembo Spa & Automobiles \& Parts \\
\hline Enel Spa & Utilities \\
\hline ENI Spa & Oil \& Gas \\
\hline ERG Spa & Oil \& Gas \\
\hline Fiat Spa & Automobiles \& Parts \\
\hline Generali Spa & Insurance \\
\hline Hera Spa & Utilities \\
\hline Indesit Company & Personal \& Household Goods \\
\hline Intesa Sanpaolo Spa & Banks \\
\hline Italcementi Group Spa & Construction \& Materials \\
\hline Lottomatica Group Spa & Travel \& Leisure \\
\hline Pirelli \& C. Spa & Automobiles \& Parts \\
\hline Saipem Spa & Oil \& Gas \\
\hline Saras Spa & Oil \& Gas \\
\hline Società Iniziative Autostrade e Servizi (SIAS) Spa & Industrial Goods \& Services \\
\hline Snam Rete Gas Spa & Utilities \\
\hline STMicroelectronics & Technology \\
\hline Terna Spa & Utilities \\
\hline Unicredit Spa & Banks \\
\hline Unipol Spa & Insurance \\
\hline & \\
\hline
\end{tabular}

Note. Source: FTSE Group.

Following this, documents produced by companies in the Dow Jones Sustainability Europe 40 Index (hereafter DJSE) were analysed, in order to understand whether CSR results in Italian companies were part of a European trend or not. The New York Stock Exchange monitors corporate sustainability performance through special indicators ${ }^{4}$. The DJSE is made up of European leaders in the field of sustainability, identified by Sam Sustainability Investing, Dow Jones' partner in constructing the index, by means of a corporate sustainability assessment.

\footnotetext{
${ }^{3}$ Criteria for inclusion in the FTSE indices measure a company's social and environmental performance quality and its governance structure with regard to the following areas: environmental policy and strategy, environmental management, products (sector specific), production process (sector specific), community relations, human resources and employees, markets and shareholders and corporate governance. The result is an evaluation over 9 levels, going from "EEE", which represents excellence, to "F", which is the lowest level.

${ }^{4}$ In particular, these Dow Jones Sustainability Indexes are constructed considering five territorial areas: Global, Europe, North America, Asia-Pacific and Korea.
} 
The index represents $20 \%$ of the larger 600 European companies in the Dow Jones Global Total Stock Market Index, following long-term evaluation based on economic, social and governance criteria. Members are selected by an evaluation system for corporate sustainability, which identifies sustainability leaders in each of the 57 industrial groups. Methodology used in constructing the index comprises both general evaluation and specific evaluation of the company's sector regarding trends in matters of sustainability. Companies are evaluated on the basis of a complex series of criteria, including climate change strategies, energy consumption, HR development, knowledge management, stakeholder relations and corporate governance.

Given that there were 40 companies in the American index, almost double those in the Borsa Italiana, we analysed the top components only, i.e., the best 10 companies in the DJSE, shown in Table 2.

Table 2

Top 10 Components in the DJSE on 30th June, 2011

\begin{tabular}{|l|l|l|}
\hline Company & Country & Super sector \\
\hline SAP AG & Germany & Technology \\
\hline ABB Ltd. & Switzerland & Industrial Goods \& Services \\
\hline AXA S.A. & France & Insurance \\
\hline Deutsche Telekom AG & Germany & Telecommunications \\
\hline Novo Nordisk A/S Series B & Denmark & Health Care \\
\hline British American Tobacco PLC & U.K. & Personal \& Household Goods \\
\hline Enel Spa & Italy & Utilities \\
\hline Allianz SE & Germany & Insurance \\
\hline Siemens AG & Germany & Industrial Goods \& Services \\
\hline Roche Holding AG Part. Cert. & Switzerland & Health Care \\
\hline
\end{tabular}

Note. Source: CME Group Index Services LLC.

CSR documentation for the 24 companies in the FELI and the 10 top components of the DJSE was obtained from company websites. Research was then carried out using successive steps. Moreover, to simplify the phase of data elaboration, data were gathered using the form shown in Table 3.

Table 3

Form Used to Gather and Organize Social Reporting Data From Companies

\begin{tabular}{|c|c|c|c|c|}
\hline & Company 1 & Company 2 & $\ldots$ & Company No. \\
\hline \multicolumn{5}{|l|}{ Year } \\
\hline \multicolumn{5}{|l|}{ Type of document } \\
\hline \multicolumn{5}{|c|}{ (1) Environmental balance sheet (report) } \\
\hline \multicolumn{5}{|c|}{ Assurance } \\
\hline \multicolumn{5}{|c|}{ (2) Sustainability balance sheet (report) } \\
\hline \multicolumn{5}{|l|}{ Assurance } \\
\hline \multicolumn{5}{|c|}{ External verification of model application } \\
\hline \multicolumn{5}{|c|}{ Added value } \\
\hline \multicolumn{5}{|c|}{ (3) Social balance sheet } \\
\hline \multicolumn{5}{|c|}{ Assurance } \\
\hline (4) Code of ethics & & & & \\
\hline
\end{tabular}


(Table 3 continued)

\begin{tabular}{|c|c|c|c|c|}
\hline & Company 1 & Company 2 & $\ldots$ & Company No. \\
\hline \multicolumn{5}{|l|}{ Reporting models } \\
\hline \multicolumn{5}{|l|}{ Social } \\
\hline \multicolumn{5}{|l|}{ (1) GRI } \\
\hline \multicolumn{5}{|l|}{ (2) AA1000 } \\
\hline \multicolumn{5}{|l|}{ (3) GBS } \\
\hline \multicolumn{5}{|l|}{ Environmental } \\
\hline \multicolumn{5}{|l|}{ (1) GRI } \\
\hline \multicolumn{5}{|l|}{ (2) Life Cycle Assessment (ISO 14040) } \\
\hline \multicolumn{5}{|l|}{ Indicators } \\
\hline \multicolumn{5}{|l|}{ (1) Environmental indicators } \\
\hline \multicolumn{5}{|l|}{ (2) Economic indicators } \\
\hline \multicolumn{5}{|l|}{ (3) Social indicators } \\
\hline (4) Cross-reference table of indicators with model chosen & & & & \\
\hline
\end{tabular}

The form has three parts, one for each specific phase of research, offering useful information for understanding the methods used by companies for their voluntary reporting and, consequently, for evaluating them.

The first part of the form comprises information regarding types of CRS documents produced by companies - environmental or sustainability balance sheets or reports, social balance sheets and codes of ethics. For the environmental and sustainability balance sheets, we also checked if they had undergone an external assurance process.

The second part concerns the models of social (GRI, AA1000, and GBS) and environmental (GRI and Life Cycle Assessment-ISO 14040) reporting used by companies.

The third and last part verify the presence of economic, social and governance performance indicators within company documents. A check was also made for the existence of a cross-reference table of indicators in the document against those in the reporting model adopted by the company, in order to see how rigorously these had been applied.

In conclusion, we looked at whether the commitment in drawing up CSR documents by companies in the FELI and DJSE indicators was continuous over time, considering that continuity in preparing social reporting documents signifies effective commitment by the company and is not merely a marketing or communications operation. To this end we verified continuity in drawing up the documents over a period of five years, excluding the code of ethics. The latter, in fact, is normally updated more than annually.

\section{Analysis of Results and Discussion}

The results of analysis of documents from companies making up the FELI and the top 10 companies of the DJSE are given separately below, for easier legibility and understanding.

\section{The FELI}

First of all, CSR documents were obtained for companies making up the FELI of the Borsa Italiana. There are 24 companies, however, for one of these, Società Iniziative Autostrade e Servizi (SIAS) Spa, documents were unavailable on the company website. It was therefore eliminated from the group.

Next, the social reporting documents produced by the remaining 23 companies were examined. The results 
of this analysis can be seen in Table 4 .

Table 4

Results of Companies Making Up the FELI

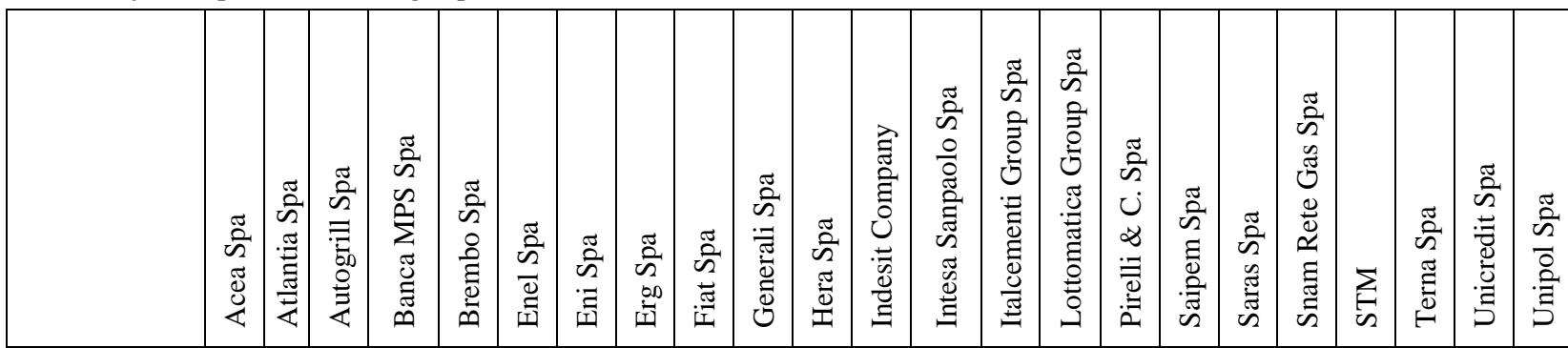

Year

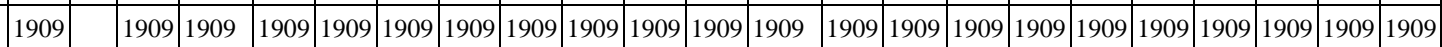

Type of document

Environmental

balance sheet $\mathrm{X}^{*}$

(report)

Assurance

Sustainability

balance sheet $X$

(report)

Assurance

External

verification of

model

application

Added value $\mathrm{X}$

Social balance

sheet

Assurance

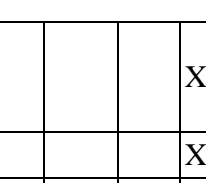

\begin{tabular}{|l|l|l|l|l|l|l|l|l|l|l|l|l|l|l|l|l|l|l|l|l|l|l|l|l|l|l}
\hline Code of ethics & & $\mathrm{X}$ & $\mathrm{X}$ & $\mathrm{X}$ & $\mathrm{X}$ & $\mathrm{X}$ & $\mathrm{X}$ & & $\mathrm{X}$ & $\mathrm{X}$ & $\mathrm{X}$ & $\mathrm{X}$ & $\mathrm{X}$ & $\mathrm{X}$ & $\mathrm{X}$ & $\mathrm{X}$ & $\mathrm{X}$ & $\mathrm{X}$ & $\mathrm{X}$ & & $\mathrm{X}$ & & $\mathrm{X}$ \\
\hline
\end{tabular}

Reporting model

Social

\begin{tabular}{|l|l|l|l|l|l|l|l|l|l|l|l|l|l|l|l|l|l|l|l|l|l|l|l|l|}
\hline GRI & $\mathrm{X}$ & & $\mathrm{X}$ & $\mathrm{X}$ & & $\mathrm{X}$ & $\mathrm{X}$ & $\mathrm{X}$ & $\mathrm{X}$ & $\mathrm{X}$ & $\mathrm{X}$ & $\mathrm{X}$ & $\mathrm{X}$ & $\mathrm{X}$ & $\mathrm{X}$ & $\mathrm{X}$ & $\mathrm{X}$ & & $\mathrm{X}$ & $\mathrm{X}$ & $\mathrm{X}$ & $\mathrm{X}$ & $\mathrm{X}$ \\
\hline
\end{tabular}

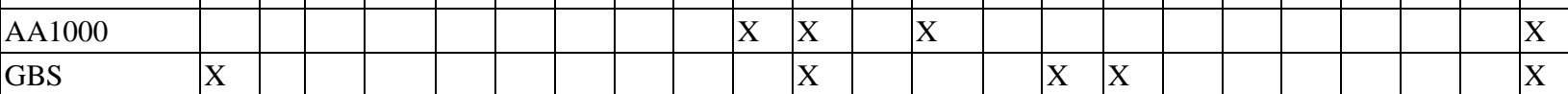

Environmental

\begin{tabular}{|l|l|l|l|l|l|l|}
\hline GRI & & & & & & $X$ \\
\hline
\end{tabular}

assessment

(ISO 14040)

Indicator

\begin{tabular}{|l|l|l|l|l|l|l|l|l|l|l|l|l|l|l|l|l|l|l|l|l|l|l|} 
Environmental & $\mathrm{X}$ & & $\mathrm{X}$ & $\mathrm{X}$ & & $\mathrm{X}$ & $\mathrm{X}$ & $\mathrm{X}$ & $\mathrm{X}$ & $\mathrm{X}$ & $\mathrm{X}$ & & $\mathrm{X}$ & $\mathrm{X}$ & $\mathrm{X}$ & $\mathrm{X}$ & $\mathrm{X}$ & $\mathrm{X}$ & $\mathrm{X}$ & $\mathrm{X}$ & $\mathrm{X}$ & $\mathrm{X}$
\end{tabular}

\begin{tabular}{|l|l|l|l|l|l|l|l|l|l|l|l|l|l|l|l|l|l|l|l|l|l|}
\hline Economic & $\mathrm{X}$ & $\mathrm{X}$ & $\mathrm{X}$ & & $\mathrm{X}$ & $\mathrm{X}$ & $\mathrm{X}$ & $\mathrm{X}$ & $\mathrm{X}$ & $\mathrm{X}$ & & $\mathrm{X}$ & $\mathrm{X}$ & $\mathrm{X}$ & $\mathrm{X}$ & $\mathrm{X}$ & & $\mathrm{X}$ & $\mathrm{X}$ & $\mathrm{X}$ & $\mathrm{X}$ \\
\hline
\end{tabular}

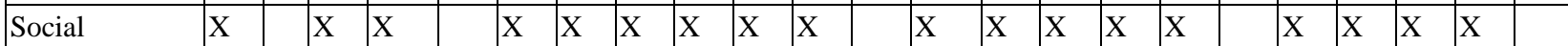

Cross-reference

table of

model chosen

\begin{tabular}{l|l|l|l|l|l|l|l|l} 
& $X$ & $X$ & $X$ & & $X$ & $X$ & $X$
\end{tabular}

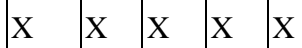

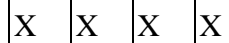

Notes. " Attachment to sustainability report; ${ }^{* *}$ The company uses the term "social responsibility" for the document, but it is sustainability reporting; ${ }^{* * *}$ The company uses the term "social balance sheet” for the document, but it is sustainability reporting; *** Model ABI (Italian Banking Association)/IBS (European Institute for Social Reporting). 
Year of reference for company documents is 2009, except for Atlantia Spa, which does not give any information. 2009 was chosen in order to carry out a homogenous comparison in terms of time. When documents were examined, some companies had not yet made their 2010 reports available.

The reporting document most commonly used by companies is the sustainability balance sheet (or report), used by 19 out of the 23 companies examined (82.61\%). Of these documents, however, only eight underwent an assurance process, while the majority relied on external evaluation regarding the way the model was applied.

Half the documents, including those of the Banca Monte dei Paschi di Siena Spa and the Banca Intesa Sanpaolo Spa who adopt a model reviewed by the Associazione Bancaria Italiana (Italian Banking Associatio-ABI) in collaboration with the European Institute for Social Reporting (IBS), contained a calculation of added value and its distribution among stakeholders.

Only one company (Intesa Sanpaolo Spa) drew up a social balance sheet, which underwent an assurance process. Only three companies drew up an environmental balance sheet-these were industrial companies.

No less than $82.61 \%$ of the 23 companies, however, prepared a code of ethics and, in some cases such as Atlantia Spa and Brembo Spa, this was the only document produced.

As far as social reporting models are concerned, the majority of companies (13 out of 23, 65\%) declared adoption of the GRI, while in other cases more than one model was used contemporaneously (see Table 5).

Table 5

Social Reporting Models Used in Documents Produced by FELI Companies

\begin{tabular}{lcl}
\hline Models used & No. & Percent (\%) \\
\hline GRI & 13 & 65 \\
GRI + AA1000 & 2 & 10 \\
GRI + GBS & 3 & 15 \\
GRI + GBS + AA1000 & 2 & 10 \\
\hline
\end{tabular}

Regarding environmental reporting, Enel Spa and Acea Spa stated the model used in drawing up their report (GRI and Life Cycle Assessment respectively), while Saras Spa, though it prepared a report, used a "personalised" structure not resembling any known standards.

Of special importance in evaluating the quality of reporting are the indicators. These make it possible to measure impact produced in the three areas of sustainability (economy, society and environment).

On this point, it should be noted that the majority of companies not only include these three GRI categories in their documents, but they also provide a cross-reference table with those of the model. In fact, only four of the reports examined do not contain the recommended indicators. However, in two cases, this concerns companies who only draw up a code of ethics (Atlantia Spa and Brembo Spa) and in one case only environmental indices are found because the company only drew up an environmental balance sheet. Lastly, Hera Spa, though it gives the indicators, does not give a cross-reference table allowing us to compare them with those originally suggested by the model.

Our analysis of documents produced by companies in the FELI ended by monitoring the five years preceding the last available version of each document drawn up by the company, to understand whether there was a certain continuity or not. The results of this analysis can be seen in Table 6 . 
As far as continuity is concerned, all companies had been reporting for several years. Only in three cases was the period of reporting less than five years.

Table 6

Documents Produced by FELI During the Five Years Preceding the Last Available Version of Each Document

\begin{tabular}{|c|c|c|c|c|c|c|}
\hline Company & 2010 & 2009 & 2008 & 2007 & 2006 & 2005 \\
\hline \multicolumn{7}{|l|}{ Acea Spa } \\
\hline Environmental Balance Sheet & & $\mathrm{x}$ & $\mathrm{x}$ & $\mathrm{x}$ & & \\
\hline Sustainability Balance Sheet & & $\mathrm{x}$ & $\mathrm{x}$ & $\mathrm{x}$ & $\mathrm{x}$ & $\mathrm{x}$ \\
\hline Autogrill Spa (Sustainability Report) & $\mathrm{x}$ & $\mathrm{x}$ & $\mathrm{x}$ & $\mathrm{x}$ & $\mathrm{x}$ & \\
\hline $\begin{array}{l}\text { Banca Monte dei Paschi di Siena Spa } \\
\text { (Social Accountability Balance Sheet) }\end{array}$ & $\mathrm{x}$ & $\mathrm{x}$ & $\mathrm{x}$ & $\mathrm{x}$ & $\mathrm{x}$ & \\
\hline \multicolumn{7}{|l|}{ Enel Spa } \\
\hline Environmental Report & $\mathrm{x}$ & $\mathrm{x}$ & & $\mathrm{x}$ & $\mathrm{x}$ & \\
\hline Sustainability Balance Sheet & $\mathrm{x}$ & $\mathrm{x}$ & $\mathrm{x}$ & $\mathrm{x}$ & $\mathrm{x}$ & \\
\hline ENI Spa (Sustainability Balance Sheet) & $\mathrm{x}$ & $\mathrm{x}$ & $\mathrm{x}$ & $\mathrm{x}$ & $\mathrm{x}$ & \\
\hline ERG Spa (Sustainability Report) & $\mathrm{x}$ & $\mathrm{x}$ & $\mathrm{x}$ & $\mathrm{x}$ & $\mathrm{x}$ & \\
\hline Fiat Spa (Sustainability Balance Sheet) & $\mathrm{x}$ & $\mathrm{x}$ & $\mathrm{x}$ & $\mathrm{x}$ & $\mathrm{x}$ & \\
\hline Generali Spa (Sustainability Balance Sheet) & $\mathrm{x}$ & $\mathrm{x}$ & $\mathrm{x}$ & $\mathrm{x}$ & $\mathrm{x}$ & \\
\hline Hera Spa (Sustainability Balance Sheet) & $\mathrm{x}$ & $\mathrm{x}$ & $\mathrm{x}$ & $\mathrm{x}$ & $\mathrm{x}$ & \\
\hline $\begin{array}{l}\text { Indesit Company (Sustainability } \\
\text { Balance Sheet) }\end{array}$ & $\mathrm{x}$ & $\mathrm{x}$ & $\mathrm{x}$ & $\mathrm{x}$ & $\mathrm{x}$ & \\
\hline $\begin{array}{l}\text { Intesa SanPaolo Spa (Sustainability } \\
\text { Balance Sheet) }\end{array}$ & $\mathrm{x}$ & $\mathrm{x}$ & $\mathrm{x}$ & $\mathrm{x}$ & $\mathrm{x}$ & \\
\hline $\begin{array}{l}\text { Italcementi Group Spa (Sustainable } \\
\text { Development Report) }\end{array}$ & & $\mathrm{x}$ & $\mathrm{x}$ & $\mathrm{x}$ & $\mathrm{x}$ & $\mathrm{x}$ \\
\hline $\begin{array}{l}\text { Lottomatica Group Spa (Social Balance } \\
\text { Sheet) }\end{array}$ & $\mathrm{x}$ & $\mathrm{x}$ & $\mathrm{x}$ & $\mathrm{x}$ & & \\
\hline Pirelli \& C. Spa (Sustainability Report) & $\mathrm{x}$ & $\mathrm{x}$ & $\mathrm{x}$ & $\mathrm{x}$ & $\mathrm{x}$ & \\
\hline Saipem Spa (Sustainability Balance Sheet) & $\mathrm{x}$ & $\mathrm{x}$ & $\mathrm{x}$ & $\mathrm{x}$ & $\mathrm{x}$ & \\
\hline Saras Spa (Environment and Safety Report) & $\mathrm{x}$ & $\mathrm{x}$ & $\mathrm{x}$ & $\mathrm{x}$ & $\mathrm{x}$ & \\
\hline $\begin{array}{l}\text { Snam Rete Gas Spa (Sustainability Balance } \\
\text { Sheet) }\end{array}$ & $\mathrm{x}$ & $\mathrm{x}$ & $\mathrm{x}$ & $\mathrm{x}$ & $\mathrm{x}$ & \\
\hline $\begin{array}{l}\text { STMicroelectronics (Corporate } \\
\text { Responsibility Report) }\end{array}$ & $\mathrm{x}$ & $\mathrm{x}$ & $\mathrm{x}$ & $\mathrm{x}$ & $\mathrm{x}$ & \\
\hline Terna Spa (Sustainability Report) & $\mathrm{x}$ & $\mathrm{x}$ & $\mathrm{x}$ & $\mathrm{x}$ & $\mathrm{x}$ & \\
\hline Unicredit Spa (Sustainability Balance Sheet) & $\mathrm{x}$ & $\mathrm{x}$ & $\mathrm{x}$ & $\mathrm{x}$ & $\mathrm{x}$ & \\
\hline Unipol Spa (Sustainability Balance Sheet) & $\mathrm{x}$ & $\mathrm{x}$ & $\mathrm{x}$ & $\mathrm{x}$ & $\mathrm{x}$ & \\
\hline
\end{tabular}

\section{The DJSE}

Analysis was then carried out into the top 10 components in the DJSE. As far as the nationality of the companies is concerned, Germany figured strongly in the index with no less than four top components. The other companies came from Switzerland (two companies), France, Denmark, Italy and the United Kingdom. The reports analysed date of the last available documents of social reporting, which was dated from 2010.

All companies involved drew up a sustainability report and had a code of ethics. There is, therefore, more homogeneity than in the Italian situation in choosing triple bottom line reporting and in adopting a code of ethics.

The majority of documents analysed (no less than seven out of 10) underwent limited auditing by an external body, audit firm or certification body. In the remaining cases, the external audit was limited to the report indicators (one company) or to a specific selection of these (two companies). 
The context and the international markets where these companies operate are reflected in their choice of reporting model. All the companies analysed opted for GRI, that is to say, for the standard enabling easier international comparison of the sustainability report. In three cases (SAP, British American Tobacco and Enel), in addition to GRI, a standard for processes like AA1000 was used.

The use of quantitative reporting, along with a qualitative-descriptive approach, is widespread in sustainability reporting. This is borne out by the use of economic, environmental and social indicators by the companies in our sample. The GRI model facilitates the use of these indicators, and of the cross-reference table between the report's contents and the indicators specified by the model.

For a synthesis of results of the empirical analysis (see Table 7).

Table 7

Results of Companies Making up the DJSE

\begin{tabular}{|c|c|c|c|c|c|c|c|c|c|c|}
\hline & 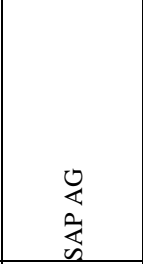 & 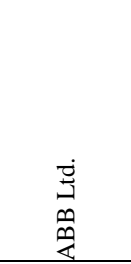 & $\begin{array}{l}\dot{4} \\
\omega \\
\overleftarrow{x} \\
4\end{array}$ & 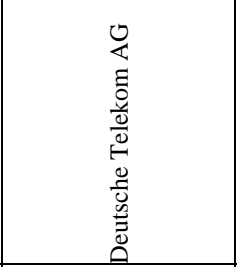 & 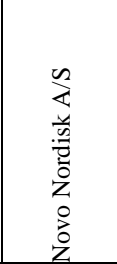 & 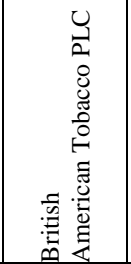 & 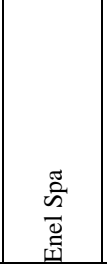 & 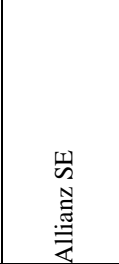 & 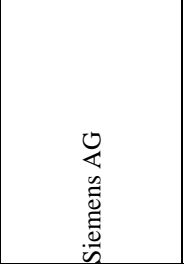 & 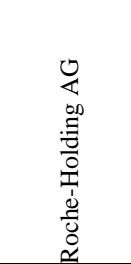 \\
\hline Country & Germany & $\begin{array}{l}\text { Switzerlan } \\
\text { d }\end{array}$ & France & Germany & Denmark & \begin{tabular}{|l|} 
United \\
Kingdom
\end{tabular} & Italy & Germany & Germany & Switzerland \\
\hline Super sector & Technology & $\begin{array}{l}\text { Industrial } \\
\text { Goods \& } \\
\text { Services }\end{array}$ & Insurance & Telecommunications & $\begin{array}{l}\text { Health } \\
\text { care }\end{array}$ & \begin{tabular}{|l|} 
Personal \\
$\&$ \\
Household \\
goods
\end{tabular} & Utilities & Insurance & $\begin{array}{l}\text { Industrial goods } \\
\text { \& Services }\end{array}$ & Health care \\
\hline Year & 2010 & 2010 & 2010 & 2010 & 2010 & 2010 & 2010 & 2010 & 2010 & 2010 \\
\hline \multicolumn{11}{|l|}{ Type of document } \\
\hline \multicolumn{11}{|l|}{\begin{tabular}{|l|l|}
$\begin{array}{l}\text { Environmental } \\
\text { balance } \\
\text { (report) }\end{array}$ \\
\end{tabular}} \\
\hline \multicolumn{11}{|l|}{\begin{tabular}{|l|l} 
Assurance \\
\end{tabular}} \\
\hline \begin{tabular}{ll|}
$\begin{array}{l}\text { Sustainability } \\
\text { balance } \\
\text { (report) }\end{array}$ & sheet \\
\end{tabular} & $\mathrm{x}$ & $\mathrm{x}$ & $\mathrm{x}$ & $\mathrm{X}$ & $\mathrm{x}$ & $\mathrm{X}$ & $\mathrm{X}$ & $\mathrm{x}$ & $\mathrm{X}$ & $\mathrm{x}$ \\
\hline \begin{tabular}{l|l} 
Assurance \\
\end{tabular} & $\mathrm{X}$ & & $\mathrm{X}^{* *}$ & $\mathrm{X}^{* *}$ & $\mathrm{X}$ & $\mathrm{X}$ & $\mathrm{X}$ & $\mathrm{X}$ & $\mathrm{X}$ & $\mathrm{X}$ \\
\hline \begin{tabular}{l|} 
External \\
verification of \\
model application
\end{tabular} & & $\mathrm{X}^{*}$ & & & & & & & & \\
\hline \multicolumn{11}{|l|}{ Added value } \\
\hline \multicolumn{11}{|l|}{\begin{tabular}{ll|}
$\begin{array}{l}\text { Social } \\
\text { sheet }\end{array}$ & balance \\
\end{tabular}} \\
\hline \multicolumn{11}{|l|}{\begin{tabular}{l|l} 
Assurance & \\
\end{tabular}} \\
\hline Code of ethics & $\mathrm{X}$ & $\mathrm{X}$ & $\mathrm{X}$ & $\mathrm{X}$ & & $\mathrm{X}$ & $\mathrm{X}$ & & $\mathrm{X}$ & $\mathrm{X}$ \\
\hline \multicolumn{11}{|l|}{ Reporting model } \\
\hline \multicolumn{11}{|l|}{ Social } \\
\hline GRI & $\mathrm{X}$ & $\mathrm{X}$ & $\mathrm{X}$ & $\mathrm{X}$ & $\mathrm{X}$ & $\mathrm{X}$ & $\mathrm{X}$ & $\mathrm{X}$ & $\mathrm{X}$ & $\mathrm{X}$ \\
\hline AA1000 & $\mathrm{X}$ & & & & & $\mathrm{X}$ & $\mathrm{X}$ & & & \\
\hline \multicolumn{11}{|l|}{ GBS } \\
\hline \multicolumn{11}{|l|}{ Environmental } \\
\hline \multicolumn{11}{|l|}{ GRI } \\
\hline $\begin{array}{|lr|}\begin{array}{l}\text { Life } \\
\text { Assessment }\end{array} & \text { Cycle } \\
\text { 14000) } & \text { (ISO } \\
\end{array}$ & & & & & & & & & & \\
\hline
\end{tabular}


(Table 7 continued)

\begin{tabular}{|c|c|c|c|c|c|c|c|c|c|c|}
\hline & 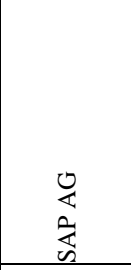 & 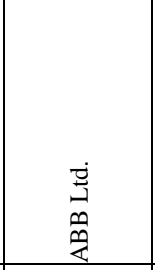 & $\begin{array}{l}\dot{4} \\
\text { m } \\
\overleftrightarrow{x} \\
\end{array}$ & 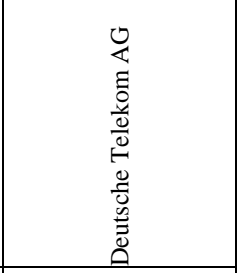 & 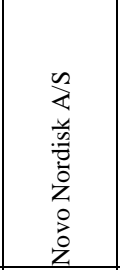 & 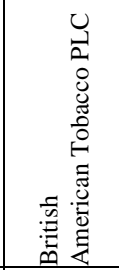 & 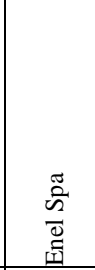 & 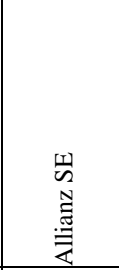 & 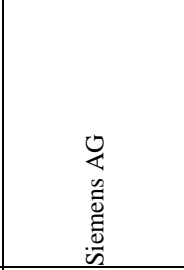 & 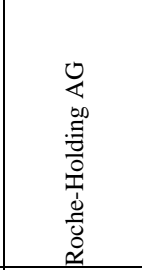 \\
\hline Country & Germany & Switzerland & France & Germany & Denmark & \begin{tabular}{|l} 
United \\
Kingdom
\end{tabular} & Italy & Germany & Germany & Switzerland \\
\hline Super sector & $\begin{array}{l}\text { Technolog } \\
\text { y }\end{array}$ & $\mid \begin{array}{ll}\text { Industrial } & \\
\text { goods } & \& \\
\text { services }\end{array}$ & Insurance & Telecommunications & $\begin{array}{l}\text { Health } \\
\text { care }\end{array}$ & \begin{tabular}{|l|} 
Personal \\
$\&$ \\
Househol \\
d goods \\
\end{tabular} & Utilities & Insurance & $\begin{array}{l}\text { Industrial goods } \\
\text { \& services }\end{array}$ & Health care \\
\hline Year & 2010 & 2010 & 2010 & 2010 & 2010 & 2010 & 2010 & 2010 & 2010 & 2010 \\
\hline \multicolumn{11}{|l|}{ Indicator } \\
\hline $\begin{array}{l}\text { Environmental } \\
\text { indicators }\end{array}$ & $\mathrm{X}$ & $\mathrm{x}$ & $\mathrm{X}$ & $\mathrm{X}$ & $\mathrm{X}$ & $\mathrm{x}$ & $\mathrm{X}$ & $\mathrm{x}$ & $\mathrm{X}$ & $\mathrm{x}$ \\
\hline Economic indicators & $\mathrm{X}$ & $\mathrm{x}$ & $\mathrm{X}$ & $\mathrm{X}$ & $\mathrm{X}$ & $\mathrm{X}$ & $\mathrm{X}$ & $\mathrm{X}$ & $\mathrm{X}$ & $\mathrm{X}$ \\
\hline Social indicators & $\mathrm{X}$ & $\mathrm{X}$ & $\mathrm{X}$ & $\mathrm{X}$ & $\mathrm{X}$ & $\mathrm{X}$ & $\mathrm{X}$ & $\mathrm{X}$ & $\mathrm{X}$ & $\mathrm{X}$ \\
\hline $\begin{array}{l}\text { Cross-reference } \\
\text { table of indicators } \\
\text { with model chosen }\end{array}$ & $\mathrm{X}$ & $\mathrm{X}$ & $\mathrm{X}$ & $\mathrm{X}$ & $\mathrm{X}$ & $\mathrm{X}$ & $\mathrm{X}$ & $\mathrm{X}$ & $\mathrm{X}$ & $\mathrm{X}$ \\
\hline
\end{tabular}

Notes. ${ }^{*}$ Only some indicators or specific content audited; ${ }^{* *}$ Only performance indicators audited.

Regarding continuity of reporting, all companies sampled have been compiling sustainability reports for five years—a sign of their commitment to the CSR concept (see Table 8).

Table 8

Documents Produced by DJSE Companies During the Five Years Preceding the Last Available Version of Each Document

\begin{tabular}{|c|c|c|c|c|c|}
\hline Company & 2010 & 2009 & 2008 & 2007 & 2006 \\
\hline SAP AG (Sustainability Report) & $\mathrm{x}$ & $\mathrm{x}$ & $\mathrm{x}$ & $\mathrm{x}$ & \\
\hline ABB Ltd. (Sustainability Report) & $\mathrm{x}$ & $\mathrm{x}$ & $\mathrm{x}$ & $\mathrm{x}$ & $\mathrm{x}$ \\
\hline AXA S.A. (Annual Report) & $\mathrm{x}$ & $\mathrm{x}$ & $\mathrm{x}$ & $\mathrm{x}$ & $\mathrm{x}$ \\
\hline Deutsche Telekom AG (Corporate Responsibility Report) & $\mathrm{x}$ & $\mathrm{x}$ & $\mathrm{x}$ & & \\
\hline Novo Nordisk A/S Series B (Annual Report) & $\mathrm{x}$ & $\mathrm{x}$ & $\mathrm{x}$ & $\mathrm{x}$ & $\mathrm{x}$ \\
\hline British American Tobacco PLC (Sustainability Report) & $\mathrm{x}$ & $\mathrm{x}$ & $\mathrm{x}$ & $\mathrm{x}$ & $\mathrm{x}$ \\
\hline \multicolumn{6}{|l|}{ Enel Spa } \\
\hline Environmental Report & $\mathrm{x}$ & $\mathrm{x}$ & & $\mathrm{x}$ & $\mathrm{x}$ \\
\hline Sustainability Balance Sheet & $\mathrm{x}$ & $\mathrm{x}$ & $\mathrm{x}$ & $\mathrm{x}$ & $\mathrm{x}$ \\
\hline Allianz SE (Sustainable Development Reporting) & $\mathrm{x}$ & $\mathrm{x}$ & $\mathrm{x}$ & $\mathrm{x}$ & $\mathrm{x}$ \\
\hline Siemens AG (Sustainability Report) & $\mathrm{x}$ & $\mathrm{x}$ & $\mathrm{x}$ & $\mathrm{x}$ & $\mathrm{x}$ \\
\hline Roche Holding AG Part. Cert. (Annual Report) & $\mathrm{x}$ & $\mathrm{x}$ & $\mathrm{x}$ & $\mathrm{x}$ & $\mathrm{x}$ \\
\hline
\end{tabular}

\section{Conclusion}

The study of documents produced by companies in the Italian sample highlights their attention to CSR issues, since in fact they draw up a wide spectrum of interdependent reports.

In general, the Italian companies analysed produced full documentation, sometimes supported by formal or substantial checks under an assurance process (34.78\%) or with external control into correct application of 
the model (39.13\%). From the point of view of true and fair representation of the company's sustainability policies, this is undoubtedly a positive finding, since these reports may be considered as an active part of management and not merely a communication tool. However, 26.87\% of companies analysed have no external guarantee as to the accuracy and coherence of documents produced.

Furthermore, documentation may be found to be rather lacking in rigour, starting with the absence-in $26.78 \%$ of cases - of the table for cross-referencing indicators with the chosen model. Also, only two of the companies draw up a code of ethics.

The most common social reporting model is the GRI, sometimes integrated with other standards. From a formal point-of-view, there is coherence between models adopted and tools used, showing an intention to provide authoritative information regarding CSR.

Little use is made of specific models for environmental reporting. This might be explained by the fact that GRI reported, adopted by the majority of Italian companies, is coherent with the decision to produce a sustainability balance sheet, and this includes economic, social and environmental aspects all in the same report. On this point, the three Italian companies that do not use the GRI model use, on the other hand, the code of ethics and the environmental balance sheet.

As far as our research hypothesis is concerned, we note, at least from a formal point-of-view, that the Italian companies studied are similar in terms of reporting. This fact might, as an initial interpretation, suggests a positive evaluation regarding the development of CSR. The results show that sustainability information in Italy is becoming more substantive, longer-term in nature and more focused on the impact of the organisation's sustainability practices rather than on the practices themselves. Moreover, increasing standardisation brings improvements in consistency and comparability and at the same time discourages manipulation of these documents solely for self-promotion.

However, if we compare results from the Italian sample with those of the European one, the latter shows more homogeneity in choosing triple bottom line reporting and in adopting the code of ethics. Furthermore, though the advantages of subjecting social reporting documents to external verification seem undisputed both in Italian and European practice, the DJSE companies had higher percentages of assurance, respectively $90 \%$ and $34.78 \%$. It should be said that controls by bodies external to the company constitute a guarantee of the correct procedures having been used in drawing up reports and, consequently, of the information contained in them. In all the cases examined, assurance was an alternative to an external verification of application of the model. In actual fact, in the interests of full and reliable information, these assessments should be considered complementary, not alternative. This might be a further improvement to be implemented, at European level too.

Finally, comparison with the European companies suggests that the Italian ones are somewhat "backward" in the types of documents produced, in the choice of social reporting models to be used and in external verification. The latter-external control—tends to encourage voluntary disclosure, as against an exercise in communications.

In conclusion, given the limits of the present study, we would recommend further development in the future, along three different lines of research.

Firstly, the analysis of CSR documents might be extended to public companies, which, although having 
excellent economic results, do not follow best practices in social reporting.

Secondly, one might verify differences due to the sectors in which companies operate, once again comparing documentation from Italian companies with that published by European ones.

Finally, examination of the reports might be extended from purely formal aspects to more substantial ones- to the content, using content analysis.

\section{References}

Abbort, W. F., \& Monsen, J. R. (1979). On the measurement of corporate social responsibility: Self-reported disclosures as a method of measuring corporate social involvement. Academy of Management Journal, 22, 501-515.

Adams, C. A., Hill, V. Y., \& Roberts, C. B. (1998). Corporate social reporting practices in Western Europe: Legitimating corporate behaviour. The British Accounting Review, 30, 1-21.

Al-bdour, A. A., Ellisha, N., \& Soh Deng, L. (2010). The relationship between internal corporate social responsibility and organizational commitment whit in the banking sector in Jordan. International Journal of Human and Social Sciences, 5, 932-951.

Andrew, N. (2010). The voluntary CSR disclosure in a corporate annual reports: Evidence from Australia. Corporate Owenership Control, 8, 49-55.

Aupperle, K., Carrol, A., \& Hatfield, J. (1985). An empirical examination of the relationship between corporate social responsibility and profitability. Academy of Management Journal, 28, 446-463.

Azim, M., Ahmed, S., \& Islam, M. S. (2009). Corporate social reporting practice: Evidence from listed companies in Bangladesh. Journal of Asia-Pacific Business, 10, 130-145.

Bendell, J. (2005). In whose name? The accountability of corporate social responsibility. Development in Practice, $15,362-374$.

Bird, F., \& Smucker, J. (2007). The social responsibilities of international business firm in developing areas. Journal of Business Ethics, 73, 1-9.

Caldwell, L. K., \& Weiland, P. S. (1997). International environmental policy. Durham: Duke University Press.

Carroll, A. B. (1999). Corporate social responsibility evolution of a definitional construct. Business and Society, 38, $268-295$.

Choi, J., Kwak, Y., \& Choe, C. (2010). Corporate social responsibility and corporate financial performance. Evidence from Korea. Australian Journal of Management, 35(3), 291-311.

Cooper, S. M., \& Owen, D. (2007). Corporate social responsibility and stakeholder accountability: The missing link. Accounting, Organizations and Society, 32, 649-667.

Cotta, M., \& Verzichelli, L. (2007). Political institutions in Italy. Oxford: Oxford University Press.

Covey, S. R. (1990). The 7 habits of highly effective people: Powerful lessons in personal chanche. New York: Fireside.

Donaldson, T., \& Preston, L. E. (1995). The stakeholder theory of the corporation: Concepts, evidence, and implications. Academy of Management Review, 20, 65-91.

Donham, W. B. (1929). Business ethics-A general survey. Harvard Business Review, July, 385-394.

Egri, C. P., \& Ralston, D. A. (2008). Corporate responsibility: A review of international management research from 1998 to 2007. Journal of International Management, 14, 319-339.

Elkington, J. (1998). Cannibals with forks: The triple bottom line of 21st century business. Gabriola Island: New Society Pulishers.

European Commission. (2001). Green Paper: Promoting an European framework for corporate social responsibility. Bruxelles: European Commission.

Falkner, G. (1998). EU social policy in the 1990s: Towards a corporatist policy community. London: Routledge.

Freeman, R. E. (1984). Strategic management: A Stakeholder approach. Boston: Pitman.

Friedman, M. (1962). Capitalism and freedom. Chicago: University of Chicago Press.

Gamerschlag, R., Möller, K., \& Verbeete, F. (2010). Determinants of voluntary CSR disclosure: Empirical evidence from Germany. Review of Managerial Science, 5, 233-262.

Garriga, E., \& Melé, D. (2004). Corporate social responsibility theories: Mapping the territory. Journal of Business Ethics, 53, 51-71.

Gay, E. F. (1927). The founding of the Harvard Business School. Harvard Business Review, July, 397-400.

Genier, C., Stamp, M., \& Pfitzer, M. (2009). Corporate social responsibility for agro-industries development. In C. Da Silva, D. Baker, A. Shepherd, C. Jenane, \& S. Miranda-Da Cruz (Eds.), Agro-industries for development. Oxfordshire: CABI. 
Graves, S. B., \& Waddock, S. A. (2000). Beyond built to last ... stakeholder relations in "built-to-last” companies. Business and Society Review, 105, 393-418.

Gray, R. H. (2001). Thirty years of social accounting, reporting, and auditing: What (in anything) have we learnt? Business Ethics: A European Review, 10, 9-15.

Gray, R., Kouhy, R., \& Lavers, S. (1995a). Corporate social and environmental reporting: A review of the literature and a longitudinal study of UK disclosure. Accounting, Auditing and Accountability Journal, 8, 47-77.

Gray, R., Kouhy, R., \& Lavers, S. (1995b). Methodological themes: Constructing a research database of social and environmental reporting by UK companies. Accounting, Auditing and Accountability Journal, 8, 78-101.

Graziano, P., \& Vink, M. P. (Eds.) (2007). Europeanization: New research agendas. Basingstoke: Palgrave.

Griffin, J. J., \& Mahon, J. F. (1997). The corporate social performance and corporate financial performance debate: Twenty five years of incomparable research. Business and Society, 36, 5-31.

Guthrie, J., \& Parker, L. D. (1990). Corporate social disclosure practice: A comparative international analysis. Advances in Public Interest Accounting, 3, 159-175.

Hartmann, M. (2011). Corporate social responsibility in the food sector. European Review of Agricultural Economics, 38(3), 297-324.

KPMG. (2011). International Survey of Corporate Responsibility Reporting 2011. Retrieved from http://www.kpmg.com/global/en/issuesandinsights/articlespublications/corporate-responsibility/pages/2011-survey.aspx

Leipziger, D. (2003). The corporate responsibility code book. Sheffield: Greenleaf.

McGuire, J., Sundgren, A., \& Schneeweis, T. (1988). Corporate social responsibility and firm financial performance. Academy of Management Journal, 31(4), 854-872.

McWilliams, A., \& Siegel, D. (2000). Corporate social responsibility and financial performance: Correlation or missspecification? Strategic Management Journal, 21(5), 603-609.

Metaxas, T., \& Tsavdaridou, M. (2010). Corporate social responsibility in Europe: Denmark, Hungary and Greece. Journal of Contemporary European Studies, 18(1), 25-46.

Mio, C. (2010). Corporate social reporting in Italian multi-utility companies: An empirical analysis. Corporate Social Responsibility and Environmental Management, 17, 247-271.

Morimoto, R., Ash, J., \& Hope, C. (2004). Corporate social responsibility audit: From theory to practice. Working Paper No.14, University of Cambrige.

O’Dwyer, B. (2003). Conceptions of corporate social responsibility: The nature of managerial capture. Accounting, Auditing and Accountability Journal, 16, 523-557.

Orlitzky, M., Schmidt, F., \& Rynes, S. L. (2003). Corporate social and financial performance: A meta-analysis. Organization Studies, 24, 403-411.

Owen, D., Swift, T., \& Hunt, K. (2001). Questioning the role of stakeholder engagement in social and ethical accounting, auditing and reporting. Accounting Forum, 25, 264-282.

Owen, D., Swift, T., Humphrey, C., \& Bowerman, M. (2000). The new social audits: Accountability, managerial capture or the agenda of social champions? The European Accounting Review, 9, 81-98.

Patton, M. Q. (2002). Qualitative research and evaluation methods. Thousand Oaks: Sage.

Pedrini, M., \& Ferri, L. M. (2011). Implementing corporate social responsibility. An exploratory study of strategy integration and CSR officers’ duty, Business and Management Sciences. International Quarterly Review, 2, 175-187.

Perrini, F. (2006). SMEs and CSR theory: Evidence and implication from an Italian perspective. Journal of Business Ethics, 67, 305-316.

Perrini, F., Pogutz, S., \& Tencati, A. (2006). Corporate social responsibility in Italy: State of the art. Journal of Business Strategies, 23, 65-91.

Perrini, F., Russo A., \& Tencati, A. (2007), CSR strategies of SMEs and large firms. Evidence from Italy. Journal of Business Ethics, 74, 285-300.

Peters, T. J., \& Waterman, R. H. Jr. (1988). In search of excellence: Lessons from America's best-run companies. New York: Harper \& Row.

Poddi, L., \& Vergalli, S. (2008). Does corporate social responsibility affect firms' performance? Paper accepted at the 10th bi-annual EACES Conference, Higher School of Economics, Moscow, Russia, 28-30 August.

Porter, M. E., \& Kramer, M. R. (2006). Strategy and society. The link between competitive advantage and corporate social responsibility. Harvard Business Review, 84, 78-92. 
Russo, A., \& Tencati, A. (2009). Formal vs. informal CSR strategies: Evidence from Italian micro, small, medium-sized, and large firms. Journal of Business Ethics, 85, 339-353.

Sacconi, L., De Colle, S., Baldin, E., Wieland, J., Oakley, R., Zadek, S., \& Cohen, J. (2003). Developing a CSR framework to integrate Q-RES and other social and ethical standards, Final Research Report, CELE-Centre for Ethics, Law and Economics, LIUC University, Italy. Retrieved from www.dnwe.de/tl_files/ZfW/200401_eu_report.pdf

Spence, L. J., \& Lozano, F. (2000). Communicating about ethics with small firms: Experiences from the UK and Spain. Journal of Business Ethics, 27, 43-53.

Spence, L. J., Jeurissen, R., \& Rutherfoord, R. (2000). Small business and the enviroment in the UK and the Netherlands: Toward stakeholder cooperation. Business Ethics Quarterly, 10, 945-965.

Thomas, G., \& Nowak, M. (2006). Corporate social Responsibility: A definition. Working Paper 62, Graduate School of Business, Curtin University of Technology, Australia.

Thompson, J. K., \& Smith, H. L. (1991). Social responsibility and small business: Suggestion for research. Journal of Small Business Management, 29, 30-44.

Thomson, P., \& Zakaria, Z. (2004). Corporate social responsibility reporting in Malaysia. Progress and perspectives. Journal of Corporate Citizenship, 13, 125-136.

Unioncamere. (2003). La responsabilità sociale delle imprese e gli orientamenti dei consumatori. Roma: Unioncamere.

Waddock, S., \& Graves, S. (1997). The corporate social performance-Financial performance link. Strategic Management Journal, 18, 303-319. 